\title{
Currently Receiving
}

National Cancer Institute

\section{Source}

National Cancer Institute. Currently Receiving. NCI Thesaurus. Code C159274.

An indication that an individual is receiving something at the present time. 